\title{
Methodological Impediments to Innovation on Political Thought of Islam
}

\author{
Ali Akbar Alikhani \\ Faculty of World Study, University of Tehran, Iran
}

Copyright (C) 2015 by authors, all rights reserved. Authors agree that this article remains permanently open access under the terms of the Creative Commons Attribution License 4.0 International License

\begin{abstract}
If research, knowledge production, and theorization are equal to innovation, we have to accept that Islamic political thought suffers from a slow movement in innovation. The small number of researches that exist in this field, repeat themselves using a different terminologies and word orders. Obstacles on the way of development of researches in Islamic political thought need to be surveyed in depth. Such a survey will probably encounter the same obstacles. This paper aims at a brief review of a number of obstacles that have been experienced during concrete research procedures by the author. The obstacles between them are not clearly identified. The first group is related to the researcher which includes: unnecessary caution, no reference to original texts, definition of the problem from an abstract perspective, no reference to concrete examples and texts. Tec second category is related to the cognitive and educational system of the Islamic world. Among these problems there are a variety of historicism, lack of centrality of knowledge and weakness of scientific procedures. The third group is affected by the scientific system of the west, in which the discussion are not defined by themselves. The last group is created in the concrete political situation of Islamic countries and includes: transformation of basic concepts in political thought in to political and ideological issues, and vulgarization of basic concepts in Islamic political thought.
\end{abstract}

Keywords Methodology, Islam, Political Thought, Islamic Research

\section{Introduction}

If we consider research to mean innovation and production of knowledge as well as theorizing, this trend has been very slow and insignificant with regard to studies carried out on political thought of Islam. Not only there are few studies in this field, but those studies are also repetition of one another using new wording. Evaluating impediments to innovation in studies on the political thought of Islam needs an independent study, which will be also probably plagued with the lack of innovation and would fall short of showing us the actual barriers. Discussing the issue that whether there is a political thought in Islam or is there sufficient grounds for innovation in the field and what are expectations from Islam in this regardi, requires an independent discourse. However, our assumption is that under certain conditions, there is a political thought in Islam and we can find answers to our political questions in Islam by observing certain conditions.ii

The current paper is a cursory glance at some impediments to innovation in this field most of which have been witnessed or experienced by the writer. These impediments will be discussed in four broad categories, though drawing sharp demarcation among those categories may be impossible because they are interrelated. The first category includes factors that pertain to researcher such as non-scholarly caution, non-reliance of studies on original texts, attention to large-scale topics and lack of repeated reference to text, as well as attention to abstract and ethereal topics. The second category includes impediments which pertain to educational and epistemological system of the Islamic world. They include lack of knowledge accumulation and epistemological stages, being locked in the past, dominance of jurisprudential approach and generalizing sanctity. The third category includes those impediments that result from effects of western scientific and epistemological system. The dominant essence of political thought of the west, ideas are not independent in themselves and discussions from both sides are not specialistic. The last category of impediments are those which result from political and government systems in the Islamic countries. They include politicization of original political concepts of Islam, non-specialistic nature of such concepts, and dominance of governments over science and knowledge.

\section{Impediments Related to Researcher}

\section{Non-scholarly Caution}

Knowledge only grows when a scientist dares to go beyond existing, accepted frames and present new discussions outside those contexts without caring for less 
important considerations and marginal restrictions. If for any justifiable or unjustifiable, wanted or unwanted, right or wrong reason, researchers focus on issues other than his research, the process of innovation will be interrupted or stopped. One of those issues is exercising too much care when confronting holy texts. Researcher would believe that since he is talking about the political thought of Islam, and his study is rooted in Islam, then anything that he writes is continuation of Islam and viewpoint of Islam, and therefore, he would believe himself unconsciously to be interpreter of divine revelations. Therefore, this will cause him to be very cautious and when talking about every issue, he will try to find scholars of the past who would uphold his viewpoints and avoids talking about anything about which he has the least suspicion or suffices to general topics about which a consensus does exist. Opposite to jurisprudent, which considers itself to be official spokesman of Islam and announcer of the edicts of God and dares to issue orders in the name of God. the type of caution exercised by philosophers with regard to political thought of Islam is incompatible with the main spirit of research and would prevent researchers of political thought to introduce novelties in full and without apprehension. The main solution to this problem is that researcher should consider his discourse as having root in his own ideas and viewpoints. He must note that despite efforts made to keep his viewpoints in line with Islam and rooted in divine edicts, they are ultimately his viewpoints and he must communicate this point directly to his audience. Another solution is that the main orientation should be determined by Islam, but detailed and new issues should be designed and organized according to his own thoughts and let the readers know that they are his viewpoints.

\section{Not Relying on Original Texts}

Another impediment to research on the political thought of Islam is that researchers do not consult first-hand Islamic sources such as Quran and Nahj-ul-Balagha as well as the political history of the early years of Islam. Most knowledge and information of researcher on the political thought of Islam has been handed down to them by Muslim scholars belonging to middle centuries and it is naturally incomplete and one-dimensional. The first thing that can show us the nature of the political thought of Islam is political style chosen by the Holy Prophet of Islam (PBUH), Quran and the political history of the early years after the advent of Islam. Although, understanding the political thought of Islam through the said sources entails special problems, there is no better way and researchers have to resort to them to know and understand the political thought of Islam. Of course, efforts needed to understand those sources will not be more difficult than efforts made to know western political thoughts; the main problem is that we have not treaded this path and the content of our higher education does not pave the way for us to do this. English language is ubiquitous in our universities and our professors are mostly western educated and transfer western ideas into their country while this is not true about Islamic studies in Arabic. The important point is that the political thought of Islam is judged from the angle of western political ideas.

\section{Attention to Large-scale Topics and Lack of Repeated Reference to Text}

If we embarked on studying Quran and Sunna with large-scale issues such as "politics and governance in Islam" in mind, we would find precious information and we would have a rich discussion ahead of us, but that discussion would not be of research value and would be probably devoid of innovation, production of knowledge, or presentation of scientific solutions. Today, it is clear that subject of a research should be accurate and to the point, such as, "freedom under government of Imam Ali (AS)" and, of course, such topics as "political freedom under Imam Ali (AS)", "political freedom of opposition under Imam Ali (AS)" and "limits of political freedom of opposition under Imam Ali (AS)" will be more accurate. If a researcher studies "politics and government of Imam Ali (AS)" there is no doubt that one of its ramifications will be freedom, but such a discussion cannot include a detailed explanation on "freedom". Another important problem is that researchers in this field do not refer to Quran and Sunna for any independent research. For example, if a researchers is studying "political freedom in Islam", and he has reviewed related verses of Quran one or more times that researcher should not rely on the same mentality or information when conducting an independent research on "political justice", or "political man" in the Quran, because each of those topics calls for a special mentality and new reference to the main text. When a researcher solely focuses on "political freedom of opponents" in Islam, certain issues are reviewed in his mind and he takes advantage of special parts of Quran and Sunna which will not be available to him under other conditions. To focus on the topic of "political justice", he should review Quran or Sunna again and thoroughly. Then, he would see that his mind finds new issues about political justice and can discover hidden aspects to it, which he could not have imagined the last time that he was reading Quran during his research on freedom. Therefore, if a researcher intends to study ten different issues in Quran and Sunna, he should refer to Quran and Sunna ten different times with renewed mentality as if he is studying that text for the first time.

\section{Attention to Abstract and Ethereal Issues}

One of the most important impediments to innovation in the field of Islam's political thought is excessive attention paid by researchers to ethereal, abstract and intangible ideas. In other words, researchers do not begin with objective issued in their discussion of politics, but attend to large-scale issues related to Islamic tenets first, about which a consensus generally exists. Such issues include importance and necessity of justice, and the fact that some Quranic verses have paid attention to justice and consider it a pillar of the universe as well as social and political system. However, they never talk about practical solutions and objective examples as well as indicators of justice in political 
institutions and society. For example, when it comes to political freedom in Islam, they only talk about freedom of Man from the shackles of worldly desires into service of God while firstly, there is no debate about this; and secondly, it has nothing to do with political freedom under a modern government. The same is true about such issues as unity of God as the common denominator of all Muslim societies and the fact that the right to set laws for people is only jurisdiction of the Almighty God. However, the main problem with Islamic countries today is not rejection of unity of God or His divine right to rule Man, but the main problem is personal or class exploitation of this concept in line with political objectives, which has given rise to such maladies as lack of meritocracy resulting in corruption, poverty, unemployment, administrative and political misconduct, lack of political freedoms and so on, which are mainly due to weak management. Governments in the world of Islam do not allow researchers to focus on details and are willing for research studies to remain limited to generalities, examples of which were mentioned before. This has barred the political thought of Islam and Muslims from grappling with major political problems and has rendered it incapable of emerging victorious when it comes to political theorization as well as major tests and challenges.

Another reason is tendency of political thought discussions in Islam to attend to more general issues and present general options as well as general nature of religious and divine topics of discussion which give rise to those thoughts. While this is a positive characteristic for religious and divine teachings - because they transcend the limits of time and place -it is not good for research on political thought. The reason is that political thought should pay attention to special topics and issues and provide solutions to related problems at any time and any place. For example, political ideas of Sohrevardi and his illuminative approach to politics and power domain show that he has merely attended to a collection of highly attractive subjective issues, which have nothing to do with the realities of politics and power.iii Discussions offered by Sohrevardi are about divine and intangible issues which have no relation to the world of politics as well as challenges and conflicting interests of politicians which have their roots deep in the vanity of man. The field of politics and the arena of power is a very good ground for manifestation of worldly desires of mankind and belongs to a field where political benefits of individuals and the governing system has the first say. Of course, there are exceptions like Imam Ali (AS), but few exceptions in human history should not give rise to discussions that are far from mainstream politics. In the arena where Imam Ali (AS) was one of the political players, other players were observing the usual style of politics with Imam Ali (AS) being an exception.

\section{Impediments Related to Educational and Epistemological System}

\section{Not Going through Knowledge Accumulation and Epistemological Stages}

Various theories should be presented according to conditions of time and place or new topics should be discussed to solve political and social problems. After going through several periods of time, new theories would be based on previous ones and researchers would find newer solutions and achieve more up-to-date theories by searching through scientific texts and theories. Accumulation of texts and theories has not been done in the field of the political thought of Islam and with regard to political and social issues and concepts. Issues related to ruler and government, are usually pivoted around imamate among Shias, while they are centered on caliphate among Sunnis. When it comes to such basic concepts as Man, justice, right, people, etc., only general discussion have been presented by relying on Quran and Sunna just to laud those concepts.

Accumulated theories and viewpoints of the past form a firm basis for every science and as long as accumulation stage has not been completed, we cannot reach the stage to produce dynamic and up-to-date theories. Therefore, when we discuss the political thought of Islam, our discussion is not based on previous theories and researcher has to fill this vacuum all by himself. The basics for new discussion should be first shaped in the mind of researcher and, of course, references should be made to some verses of Quran and traditions too. On the other hand, new discussions never replace old, less valuable ones or cover their weaknesses because there are basically no previous discussions in the form of an epistemological system. iv

To achieve an epistemological system regarding the political thought of Islam, the new topics (apart from their high quality from the viewpoint of innovation) should firstly, reach a point in terms of quantity that during a specified period of time (at least, during 40 years) and with regard to a certain topics, they could form a continuous network. This means that hundreds of books and papers should be written on a special topic and over a certain period of time to result in accumulation of knowledge. Secondly, every one of those written works should focus on a special angle of subject of discussion or if they pertain to those aspects that have been previously explained by other researchers, they should focus on those aspects which have been ignored by other researchers or criticize their viewpoints. In other words, they should not suffice to repeating the same issues in various forms; just in the same way that many papers were published during Imam Ali (AS) year which were only repetition of one another. Thirdly, in addition to accumulation of knowledge about a specified issue, accumulation of topics should also take place and this should happen for many topics related to the area of political thought to lead to establishment of a continuous network for production of knowledge on various issues related to political thought. Otherwise, if production of knowledge and thought is carried out in an inorderly manner, even if they are of the highest importance and most innovative nature, they will not find a good place among the 
multitude of organized discussions (mostly western) and will be gradually forgotten.

Also, paying more attention to personalities with less attention to knowledge has prevented establishment of a continuous epistemological current with regard to political science in the world of Islam. The knowledge should stem from Quran and Sunna, and be made strong in the course of history through addition of past experiences. Nasr Mohammad Aref correctly points out that great Muslim thinkers such as ibn Khaldun, al-Farabi, Avicenna, al-Ghazali, Mavardi, and others have always been studied as human phenomena whose thoughts are results of their intrinsic genius, but the course of their intellectual development and effect of every one of them on others, has never been taken into consideration. Although Aref believes that an epistemological continuity can be tracked among them, it is not the case with regard to political thought. This has caused discussions about political thought of Islam to be individualized and not be based on political thoughts themselves. As a result, analysis of political and social conditions of emergence of thoughts and understanding the effects of time and place, which are among the most basic tools for understanding any new idea, has been totally forgotten and, more importantly, no scientific accumulation has taken place with regard to the political thought of Islam.

\section{Excessive Attention to the Past}

An impediment to innovation in the political thought of Islam is that the researcher, due to personal reason (his own mind frame) or because the atmosphere governing scientific circles and even political conditions would not allow him, cannot express his modern interpretation of Quran and Sunna and get response to his questions directly from Quran or Sunna. For this reason, they deem it necessary that to prove their rightfulness; they should quote similar cases in the written works of previous scientists and bring examples of past scholars in order to back up their own argument. Sometimes, this gives rise to several problems for some reasons: firstly, scientists and scholars of every time have lived and written under specific conditions of their own times, which were a byproduct of political and social atmosphere of their time. Scientific specialties did not exist in the past as they do today and science was not as advanced as it is now. The whole corpus of human knowledge was not comparable to modern times both in terms of quality and quantity. For this reason, problems currently faced by a specialist of political thought or the atmosphere governing a specialist researcher of this field, were totally meaningless and incomprehensible for Muslim scholars in bygone eras.

Secondly, Muslim scholars and pundits of the past eras had their own special problems and their works gave responses to those problems. Meanwhile, a Muslim researcher in new times is faced with special problems and challenges of his own time which are basically different from problems and challenges faced by their predecessors. Some of modern problems that face us today were not even conceivable for past scholars. Therefore, since current problems differ from the past, they sometimes impose their own ideas on scholars of the past or recount their arguments in such a way as to justify their own viewpoints and this is an obvious drawback.

Thirdly, when a researcher of the political thought of Islam is engaged in studying and taking notes from the works of past thinkers and is absorbed in the scientific and intellectual conditions of those times in order to better understand their views, he will be unwontedly affected by their writings and thoughts and what he writes will end up to be inspired by his predecessors. Therefore, style of writing, content, and issues discussed as well as the logic governing scientific work of a modern researcher of the political thought of Islam is not similar to modern literature and has less things in common with its counterparts in the political thought of the west.

Fourthly, use of scientific works of the past by a researcher, will take up a lot of his time and energy due to many differences in narrations and written works that are currently available, especially taking into account that such written and oral works are not classified or summarized and there is no succinct history of any science or viewpoint. Therefore, if a researcher spends 100 units of time and effort to find response to a question in Quran and Sunna, 80 units of it are spent on understanding and elucidating viewpoints of past scientists and the remaining 20 units will not be sufficient to attain his goals. Another important point is that the above four factors will automatically impose intellectual and methodological conditions on the researcher which will deprive him of any innovation and prevent him from giving modern answers to present problems. Although, he began his research in the hope of presenting a modern discourse, ultimately what happens is not that "a Muslim researcher in the $21^{\text {st }}$ century refers to Quran and Sunna to find answers to problems and succeeds", but what happens is that a researcher of the $21^{\text {st }}$ century only reviews the problems and answers of the past scholars. In other words, the knowledge and thought of past thinkers is reproduced through a modern researcher. This is nothing but to impose historical experiences of our ancestors on the realities of today.

Researchers and their audience are well aware that what we mean is not to despise the intellectual products of the past scholars by limiting them to their own age or downplaying their true value, but studying their works is a must if we are to understand the course of their thoughts. We have to know what scientific and practical reaction has been shown by pundits and knowledgeable person of every age when confronting challenges as well as intellectual and political problems of their age; what has been their intellectual and scientific efforts and what has been political and social consequences of their thoughts. However, we mean that such thoughts and ideas should be reviewed and studied within their historical frames and under political and social conditions of those times and they should not be allowed to willingly or unwillingly impose themselves on intellectual problems and challenges as well as political and social realities of the modern world through a modern researcher. 


\section{Dominance of Jurisprudential Approachv}

Of course, the main goal of delving into religious sources from the beginning was to gain more knowledge about Islamic issues, as the realm of Islamic knowledge expanded through confronting new problems and answers were given to each of those problems, and as interpretations, written works and viewpoints of Muslim scholars were added to them, scientific domains were established and every one of those domains became qualified to be considered a specialistic field, with the most important specialistic field being figh or Islamic jurisprudence. vi Fiqh found its rightful place more rapidly and became very influential due to a host of reasons; so that, in some instances it exploited other branches of knowledge including interpretation, traditions and Rijal (a branch of Islamic knowledge which sees into authenticity of those who have quoted hadith from the Prophet (PBUH) and imams (AS)). The main task of figh was to give answers to Muslims in confrontation with everyday problems and behaviors by dividing human acts and behaviors into such categories as obligatory, prohibited, recommended, reprehensible, and permissible. Therefore, there was no need for figh to get involved in complex scientific and abstract discussions and it was mainly based on quotes. The highest level of innovation and scientific complexity of fiqh was inferring answers to newly emerging problems, again on the basis of quotes from the past. Inferences about new problems should have been rooted in similar reasons in tradition and Quran and when there was no way to use indirect arguments or reference to similar cases when facing a new problem, finding an answer would have been very difficult. In general, such problems remained unanswered or when necessity called, a fatwa (as viewpoint of a mujtahid in accordance to expediencies of that time) was issued about the given problem. In this way, fiqh shunned scientific complexities from the beginning and had its roots in quotes with its goal being limited to inferring religious rules. vii Therefore, it was natural for this discipline to stay away from complex issues related to creation, mankind, society and hundreds of other specialistic political and social issues and when discussing such issues, fiqh did not go past inferring religious rules related to them and showing people what to do when facing them.

There were other Islamic sciences which relied more on ration and paid attention to issues which were of interest to them because their ultimate goal was not to tell Muslims what to do, but scientific exploration to understand various aspects of an issue. Among such disciplines, one may refer to ethics, interpretation (of Quran) and perhaps Islamic philosophy. If a major change was to be made with regard to research on the Islamic political thought, it should have happened to those sciences too because the way was paved for it. The reason why that change did not happen was that those sciences which were capable of change were marginalized, especially after collapse of the Islamic civilization in about the sixth or seventh century $\mathrm{AH}$ and were superseded by fiqh. Fiqh was accepted by the society and political systems, but was incapable of solving complex rational problems and was not able to come up with new political and social theories and basically, did not consider that to be its duty. Attention to political issues in ethical works written by ibn Moskuyeh Razi; Khajeh Nassir-ed-din in his book, Akhlaq Nasseri; and Mohaqqeq Sabzevari in his book, Rozat-ol-Anwar Abbasi, could not achieve much. Therefore, the political thought of Islam was limited to jurisprudential issues which paid attention to reviving religious tenets, ordering good and prohibiting vice, apostasy... in domestic policy as well as preventing domination of foreigners, contracts for behaving with non-Muslims and... in foreign policy. Such issues, as we said before were based on quotes and were expressed in the simplest way. Although they could meet political and social needs of their time hundreds of years ago, they did not follow complexity of those needs in the course of time and it seems that if they continue on the same path, they will not be capable of meeting the needs of a modern society. Even jurisprudential books that have been written in recent years have attended to such important issues within the old jurisprudential frames. viii This trend has had four consequences. Firstly, issues of political thought have not been established in Islam within scientific and theoretical frames commensurate with advancement of political and social systems. Secondly, some came to believe that Islam basically lacks the capacity to give rise to political thought and theorization in this field. Thirdly, many researchers whose goal is to delineate the political thought of Islam pursue this goal within jurisprudential frame and their efforts, therefore, is not possible to prove fruitful. Fourthly, proponents of a dynamic political Islam in the modern world try to defend their viewpoints on the basis of political and jurisprudential bases and the opposite side does not consider their defense to be serious or convincing. Even jurists who pay attention to such modern issues as democracy, human rights, structure of the Islamic government, party politics, political participation, and so on; do not discuss such issues in depth. ix Apart from that, fiqh has become basically stagnant with respect to new topics and it seems that there is no way to infer solutions to new problems from old texts. $\mathrm{X}$

\section{Generalizing Sanctities}

As a divine religion, Islam is sacred, but the most important question is about range of that sanctity in human life and, especially with regard to politics and governance. There has been consensus among Muslims and Muslim scholars in the course of history about sanctity of Quran and Sunna and Shias have added traditions of Infallible Imams (AS) to them. Scientific arguments have been allowed in this field, but with due care for their sanctity. This emphasize is because every one of traditions pertains to certain conditions and in response to a specific problem and the necessity for paying attention to these topics has led to emergence of Quranic sciences, interpretation of Quran, figh of traditions and other scientific fields. Therefore, there is no doubt that Quran, traditions and Sunna are sacred, but does that sanctity apply to debates that Muslim scholars conduct on them? 
Obviously, they are humans and human beings are affected by family as well as political and social conditions. Understanding and thought of people in every time is limited and proportionate to conditions and scientific advancements of that time and this limitation on human understanding, which is prerequisite of being a human being is quite natural. On the other hand, one of the most important characteristics of Quran and Sunna is that they are perennial, especially that part which is not subject to conditions of time and place. Scientific theories are willing to last a long time provided that they could overcome opposing theories or do not allow them to emerge. When political thought is directly related to Quran and Sunna, a theory is apt to become lasting by being attributed to Quran and Sunna. In this process, the words and ideas of a mortal creature will be placed along the words of the immortal God. In other words, they are willing to consider their own ideas as being the word of God, which has been uttered by them. In this way, any criticism of those ideas will be considered as tantamount to criticism of the words of God and their rejection is equal to rejecting divine revelation. This will close the door to innovation and no new theory could challenge such theory. Innovation is only possible when the main pillars of that theory are confirmed and only less important points are subject to innovation (and that should not take shape as outright rejection). In this case, accepting the pervious theory and adding something to it will be of no objection. However no theory or viewpoint is allowed to weaken frame of previous theories and take its place. During history when new problems emerged, there was possible for thinkers to come up with new ideas and political thought and since those theories were attributed to diving revelation, they blocked the way to presentation of other theories.

Due to the said trends, we only see a single period (for the first and the last time) during which theories and knowledge was produced. When new issues emerged in later ages, we also see a single period during which those theories were expanded. However, there is no sign of that new theories with quite different fundaments were produced to replace older ones. Perhaps one could say that this is because in Islam everything ends in the unity of God. But this is not a correct answer because new and totally different theories can be presented despite the existence of the principle of unity of God.

As we said before, the main reason that barred presentation of new theories was that early theories and viewpoints were attributed to divine revelation and did not allow emergence of new theories. This required certain tools which were lacking with regard to knowledge and research because knowledge and research are basically argumentative and the essence of knowledge is search for truth, which is based on thought and argumentation. Any tool used for eliminating a rival theory will be in conflict with the essence of science and cannot be created inside knowledge. Therefore, early theorists were forced to use such tools as calling opponents heretic in order to make their theories lasting by attributing them to divine revelation. Though early theories which were attributed to divine revelation resisted any kind of innovation, what happened later, equipped them with a weapon which practically barred the way to emergence of new ideas. Introduction of the new tool developed the challenge to practical fields and physical encounters and totally changed the balance. Those who used excommunication as a tool needed a supporting power to achieve their goals. Therefore, other political and social factors including need of rulers and powerful figures to theories and support of those scholars, led to union between the two groups. The calamity that followed was that the goal of knowledge (or scholars) and the goal of politics became one; that is, if the goal of knowledge and thought was to achieve truth and the goal of politics was to gain profits, when knowledge and power were united, knowledge and thought followed suit with power and from that time, the goal of scholars was not truth and not even their own benefit, but the benefit of rulers and powerful figures. The end result of this complex process was preservation of theories which were attributed to divine revelation. Another spinoff of that state of affairs was lack of any innovation in introducing new theories.

\section{Impediments Stemming from the West}

\section{Dominance of Essence and Frame of Western Political Thought}

An important impediment to innovation in the political thought of Islam was dominance of the western political thought on the minds of researchers of political thought of Islam and sometime arguments related to political thought of the west or ancient Greece are used as the main tool for assessment.xi In the world of Islam, in general, and in Iran, in particular, all discussions of political thought have their roots in ancient Greece and continue up to now after going through different periods of time. All existing topics and concepts in the history of the political thought and the contemporary political thought of the west are thoroughly studied and discussed at universities by intellectuals. At the same time, when it comes to discussions and lessons related to the political thought of Muslim scholars, only the works of few political thinkers including al-Farabi, Khajeh Nassir-ed-din Tousi, Avicenna and Khajeh Nezam-al-Mulk have been reviewed and it is always reminded that those thinkers were heavily influenced by political thoughts in ancient Greece. Meanwhile, according to a study carried out by Nasr Mohammad Aref, only the works of 18 percent of Muslim scholars in the field of political thought of Islam have been known by our researchers and 82 percent still remain unknown an none of the researchers of political thought of Islam have referred to more than 6 percent of the known sources in their studies.xii The fact that 82 percent of Muslim political thinkers and their ideas are unknown to researchers of the political thought of Islam, on the one hand, and dominance of works and ideas of western political 
thinkers, on the other hand, have shaped mental frameworks of our researchers in such a way that have deprived them of any innovation and have even made such innovation unimaginable. Some of them have reached a point where they believe "that's all its there" and there is nothing more beyond the last achievements of western political thought. According to this notion, western knowledge and wisdom is developed, global knowledge and a wisdom which should be accepted by other cultures and civilizations. xiii

Political thought of Muslims both in the middle centuries and new period, has been based on Greece and western ideas, which has made this knowledge move in such a way as to conform to epistemological system of ancient Greece or the west. For this reason, many political components stemming from Islam have no place in the political thought of Muslims and have been marginalized by jurisprudential or moral discussions. The epistemological fundaments of Islam and Greek philosophers are basically different from one another and Muslim philosophers have tried to forge a compromise between their own thoughts and those of Greek philosophers. Now, a large part of studies on the political thought of Islam belong to philosophers of Middle Ages of Islam. Since they were influenced by Greek philosophy xiv and have no conflict with other parts of system of political thought of Muslims (which are rooted in ancient Greece), if new political discourses such as those presented in Nahj-ul-Balagha are introduced into this system, they will look odd.

Omnipresence of Greek political thought in the middle centuries of Islam and influence of western political thought in the modern ages in the Islamic world and among Muslim thinkers has led to the firm notion that basically Islam lacks political knowledge and thought and no coherent and systematic political discussion could be tracked or compiled within frame of Islam.xv Meanwhile, 82 percent of Muslim thinkers and political scholars are still unknown to researchers and a book like Nahj-ul-Balagha which contains political thoughts of Imam Ali (AS) has never been seriously studied by political thinkers and researchers while it seems to be capable of being a good basis for producing a big corpus of political knowledge. Believing in excerpting from Greece, has progressed to the point that even some discussions and fundaments, which have been taken from Islam, are believed to be excerpted from ancient Greek philosophers.xvi

\section{Lack of Self-existent Discussions}

Another important impediment to innovation in the political thought of Islam is lack of a self-existent theory. The current political though of Islam which is being discussed by Muslims has emerged under the intellectual and epistemological atmosphere of the west and is trying to retrieve or bolster itself under that intellectual atmosphere or to make itself distinct from other types of political thought. However, the more it tries to retrieve its independent identity, the more it loses that identity because it has distanced from its own grounds and is based in alien ground. Basically, this outwardly Islamic entity was born in the house of a stranger from the beginning. Nasr Mohammad Aref and Hassan Hanafi correctly refer to the fact that the European wisdom made the world believe that its culture and evolutionary course of its ideas is tantamount to culture and ideas of all humanity and called on others to find their place in the circle with others accepting that offer. Under those conditions it was natural for books on political thought to rise from ancient Greece and after passing through Rome, Middle Ages, renaissance and period of Illumination end in contemporary western political thoughts. This means that the history of Europe has been taken to mean the history of the whole world while history, ideas and civilizations which once existed in ancient Iran, India, China, Egypt and Mesopotamia were easily ignored and had to retrieve themselves in the course of the European history. xvii As long as the political thought of Islam has not been put in the right context and does not retrieve itself under its own epistemological atmosphere, it will not achieve dynamism and innovation.

\section{Non-specialized Discussions on Both Sides}

An impediment to research on political thought of Islam is presence of presumptions of western political thought in the minds of researchers active in this field. To put it more precisely, researchers of the political thought of Islam can be divided into two broad groups. First, a group who know political sciences and prevalent political thought in the west and have studied in that field before embarking on research on the political thought of Islam. The second group is those who have not studied the existing political science and philosophy and are not specialists in that field, but study the political thought of Islam and write papers on it. The works of this group fails to draw attention from scientific and specialistic circles of political thought because they are outside the sphere of political sciences and are strangers to scientific literature of its specialists. Therefore, innovation is not imaginable for this group because what they write lies outside the common practice of political sciences. Researchers in the first group and specialists of political sciences who study the political thought of Islam are usually faced with a major problem; that is, they start studying the political thought of Islam through their mentality about the context and content of western political thought while the context and content of western political thought is quite different from Islam's political thought and this leads to a conflict which will end in lack of innovation for researchers on the political thought of Islam and makes political scientists believe that Islam lacks a political thought. For example, the main subject of politics in the political thought of the west is power while the main subject of political thought of Islam is not power. The writer of this paper believes that the essence and the main topic of politics in the political thought of Islam is the concept of "right". A large part of the political thought of the west which pertains to people of focused on issues related to civil institutions of the west, which have no counterpart in Islam and introducing them into Islamic countries may elicit violent reactions from 
Islamist and fundamentalist groups. However, in Islam, interaction between people and government is done through such mechanisms as "ordering good and prohibiting vice". Therefore, four groups make mistakes in this regard:

Firstly, some researchers of the political thought of Islam are looking for civil institutions in Islam and try to extract those institutions from teachings of Islamic and forge a compromise between the two.

Secondly, most religious intellectuals as well as ulema and scholars who believed in dynamism of Islam and have found out that Islam is dynamic, have tried to show through speeches or written works (which are more superficial that the works of the first group) that Islam is compatible with democracy from various viewpoints.xviii

The third group is bigoted Islamists who believe that Islam is basically incompatible with democracy and people under an Islamic system should only obey orders and fulfill their obligations.

The fourth group, who believes that Islam should not interfere in politics and believe in incompatibility of Islam with democracy, point to behaviors of the third group and maintain that the political system of Islam is based on obligation and obedience and people have no other role but to obey orders and fulfill obligations.

Obviously, the abovementioned problems stem from written works and thoughts of two groups of thinkers: firstly, specialists in Islamic sciences who are not specialists in political matters; and secondly, political thought experts who have no specialty with regard to the Islamic sciences.

\section{Political Impediments Related to Government}

\section{Ideologizing and Politicizing Original Political Concepts of Islam}

Another impediment to innovation in political thought of Islam is ideologizing some original political concepts of Islam. Since the rule of Umayyad up to the collapse of Ottoman Empire in 1924, Muslim rulers always governed a vast Islamic country in the name of Islam and they were outwardly committed to religious rites and rituals. Naturally, meeting the interests and political expediencies of every government is of the highest priority to its rulers and those governments exploited Islam to strengthen the pillars of their rule. Islamic teachings and tenets played a pivotal role in this regard. The exploitation of religion had two features:

Firstly, it lasted for a very long time and more than 1,000 years and that long period led to institutionalization of that culture.

Secondly, it was very widespread in such a way that it covered all people in the society as well as scientific centers and schools. Meanwhile, if few scholars or few centers dared to express viewpoints contrary to the mainstream, their viewpoints failed to produce an effect and were not followed by practical results.
Therefore, the basic political concepts of Islam were turned into an ideological weapon for more than 1,000 years and over a wide expanse to suppress those who opposed tyranny of caliphs and kings and provided rulers with a sacred and efficient tool through which they could dupe people; threaten, exile or kill opposing scholars; and buy courtier scholars while making them believe that killing and prosecuting the opposition would deserve divine rewards in the Afterworld. Naturally, under such oppressive conditions and over such a long period of time, no profound theoretical, intellectual or scientific discussion about the basic concepts of Islam was possible and we are now faced with a collection of political concepts which more than being profound, accurate and academic, look like publicity slogans and media propaganda tools which are of no use, but to be exploited by governments.

\section{Distancing Original Political Thought of Islam from Specialization}

Another impediment to innovation in the political thought of Islam is reducing original political concepts of Islam to a handful of slogans. Contrary to the political thought of the west whose political discussions are carried out in academic circles among thinkers and philosophers, the fields of practical and theoretical politics were mingled in the Muslim world since the very beginning and this was a result of the indispensable role of people in political fields. The ruling system had to keep in touch with ordinary people and convince them that it is based on the Islamic tenets.

It was from this point that the basic and original concepts of Islam, before being discussed by scientific circles and scholars, turned into a tool to cement relationship of rulers and ordinary people. Meanwhile, preachers played the main role for delineation of such issues. They had to speak in such a way as to be suitable for their sermons, take expediencies of the ruling system into consideration, and appease the lay people. Therefore, Islamic concepts were reduced to very low levels and continuation of this trend for more than about 1,000 years prevented basic political concepts of Islam to find their way into scientific circles and to be discussed in depth and seriously by scholars. Subsequently, those concepts did not attain epistemological depth. At present, political thought experts are faced with a collection of terms loved by lay people, but lacking in methodology or complexity to deserve political research and, therefore, this makes them believe that Islam lacks a political thought. Researchers working on the political thought of Islam are faced with a similar problem. The difference is that they seek to compile and come up with new theories in this field, but handling such concepts as slogans, will prevent them from moving toward their destined goals. For example, "ordering good and prohibiting vice" is one of the most important and most comprehensive principles and political concepts in Islam whose field of action includes the most basic and the most serious issues of the country, which is the field of power institution and governance and comes down to individual arenas. Though it aims to improve the situation in 
all fields, its main goal is to reform the government and this is indicated by reviewing the political history of early years after the advent of Islam. However, today only few researchers and political scientists associate this principle with such issues as political supervision theories, accountability, impeachment, freedom of opposition, meritocracy, elimination of political corruption, change of government.... On the contrary, when they hear about this principle, the first thing that comes to their minds is such nonpolitical and trivial matters as ordering women to observe their Islamic dress code, avoiding of dancing or singing, wearing indecent clothes and the like.

\section{Dominance of Governments over Science and Knowledge}

In the modern world, privacy of people has greatly reduced and influence of governments has increased. Science, knowledge, as well as scientific, research and academic circles are completely and systematically under dominance of governments. Although, severity of that dominance, which determines the orientation of scientific activities, differs according to country and various topics, the field of humanities and political studies are strictly controlled by governments.xix This will cause restrictions for researchers and pundits and they have to tackle many types of limitations and unwanted restrictions, which ultimately lead to lack of innovation in Islamic political thought research. There is no doubt that such restrictions will not be to the benefit of societies and governments in the long run, but the main point is that every government only pursues its short-term benefits.

\section{REFERENCES}

[1] Abdulqader Abufares, Mohammad, al-Nezam ul-Siyasi fil Islam, Jordan: Dar ol-Furqan, 1986

[2] Abdulhaq, Farid, Fil Figh al-Siyasi al-Islami, Cairo, Dar ol-Shorouq, 1419 AH/1999

[3] Abdulkabir, Abdulhei bin al-Katani, Nezam al-Hokumah al-Nabawiyah, comments: Ali Mohammad Dandal, Beirut: Dar ul-Kotob al-Ilmiyah, $1422 \mathrm{AH} / 2001$

[4] Abdulkarim, Khalil, Dowlatah Yathrib, Egypt: Sina Lilnashr va Moassissah al-Intishar al-Arabi, 1999

[5] Alikhani Ail Akbar, Islamic Political Hihmat(Philosophy):F oundational Concepts, Tehran: Iranian Institute of Philosophy Press, 2015.

[6] Alikhani Ali Akbar, Political thought of Muslim Thinkers (19 volumes), Tehran: Research Institute for Social and Cultural Studies' Press, 2011.

[7] Aliyah, Samir, Nazariyah al-Dowlah va Adaabuha fil Islam, Beirut: al-Muassisah al-Jame'iyah Leldirasat val Nashr val Tozi, 1408 AH/1998

[8] Al-Khatib, Abdulkarim, al-Khilafah val Imamah, Beirut: Dar
ol-Ma'refah, 1359 AH/1975

[9] Al-Badwi, Abdulrahman, Usul al-Yunaniyah Lel-Nazariyat al-Islamiyah al-Siyasiyah, Cairo, Maktabatol Nehzatol Mesriyah, 1954

[10] Al-Bahi, Mohammad, al-Din val Dowlah min Towjihi Quran al-Karim, Beirut: Dar ol-Fikr, 1391 AH/1971

[11] Amid Zanjani, Abbasali, Political Fiqh: International Rights and Commitments and Diplomacy in Islam, Tehran, Samt Press

[12] Khosropanah Abdolhossain, Seeking for the Islamic Humanities, Qom: Office for Islamic Knowledge Press, 2014.

[13] Hossein Yaghoub, Ahmad, al-Nizam al-Siyasi fil Islam, Beirut: al-Dar al-Islamiyah, 1417 AH/1996.

[14] Hamidollah, Mohammad, Majmuatol Wathaeq-ol-Siyasah, Tehran, Soroush press, 1999.

[15] Hanafi, H.\& Mohamad A.J, Dialogue between cultures. Translated by Mohamad, M.Kh., Tehran: Naghd \& Nazar, No, 9, 1996.

[16] Hanafi, Hassan, Homum al-Fikr wal Watan", al-Qahirah dar ol-Qoba, 1998.

[17] Hanafi, Hassan, "al-Fithqah wal Torath”, in "al-Falsafatil Arabiyah al-Muasir", Beirut: Dirasat al-Wahdah al-Arabiyah Center, 1988

[18] Hassan Abbas Hassan, Logical Structure of Political Thought of Islam, Mostafa Fazaeli, Qom: Boustan Ketab Press, 2004.

[19] Lakzaei, Sharif, “A Study of Situation of Political Philosophy in Iran", Pazhouhesh va Hozeh (Research and Seminary) quarterly, No. 21-22, 2006.

[20] Malekian, Mostafa et al., "Discourses of Philosophy of Fiqh", Qom: Office for Islamic Knowledge Press, 1998

[21] Mehdi Shamseddin, Mohammad, Fi al-Ijtima al-Siyasi al-Islami, Qom: Dar ol-Thiqafa Liltiba'ah val Nashr, 1414 $\mathrm{AH} / 1994$

[22] Moballeghi Abdolmajid, Innovation and Religious Studies, Qom: Research Institute for Islamic culture and Knowledge, 2013.

[23] Movahed Abtahi Seyed Mohammad Taghi ,"Producing Religious Knowledge Based on Dr. Soroush' viewpoint" Philosophy of Religion Quarterly, Volume 2. N. 1, 2013.

[24] Mujtahid Shabestari, Mohammad, A Critique on Official Interpretation of Religion, Tehran: Tarh-e No Press, 2000

[25] Nasr Mohammad Aref, Islamic Political Sources and Works, translation and comments: Mehran Esmaeili, Tehran, Nei Publications, 2005

[26] Rashad, Ali Akbar, "Contemporary Religion Studies", Tehran, Islamic Culture and Thought Research Center, 2005

[27] Salim al-Awa, Mohammad, Fi al-Nizam al-Siyasi Leddolatel Eslamiyah; Beirut, Cairo, Dar ol-Shoruq, 1410 AH/1989

[28] Shakouri, Abolfazl, Political Figh of Islam, Qom: Office for Islamic Propagation Press, 1998.

[29] Sharifi Enayatollah et all, "Religious Knowledge and Religinazation of Knowleges" Ghabasat Quarterly, Volum 18, N.67, pp 34-55, 2013. 
[30] Yousef al-Qarzawi, Min Fiqh al-Dowlah fil Islam, Cairo, Dar ol-Shorouq, 1419 AH/1999.
[31] Zekaria, F., Philosophy prospectes, Beirut: Daral Tanvir \& almarkaz alsaghafi press, 1988. [i] This question has been posed by Mujtahid Shabestari. See: Mohammad Mujtahid Shabestari, A Critique on Official Interpretation of Religion, Tehran, Tarh-e No Press, 2000, pp. 101-106. Also see: Seyed Mohammad Taghi Movahed Abtahi,"Producing Religious Knowledge Based on Dr. Soroush' viewpoint" Philosophy of Religion Quarterly, Volume 2. N. 1, 2013. Enayatollah Sharifi et all, "Religious Knowledge and Religinazation of Knowleges" Ghabasat Quarterly, Volum 18, N.67, pp 34-55, 2013. Abdolhossain Khosropanah, Seeking for the Islamic Humanities, Qom: Office for Islamic Knowledge Press, 20014

[ii] With regard to existence of politics and political thought in Islam, See: Mohammad Hamidollah, Majmuatol Wathaeq-ol-Siyasah; Mohammad Salim al-Awa, Fi al-Nizam al-Siyasi Leddolatel Eslamiyah; Beirut, Cairo, Dar ol-Shoruq, 1410 AH/1989, pp. 42-64 and 116-143; Mohammad Mehdi Shamseddin, Fi al-Ijtima al-Siyasi al-Islami, Qom: Dar ol-Thiqafa Liltiba'ah val Nashr, 1414 AH/1994, pp. 74-78, 84-87, 159-169, and 515-599; Mohammad Abdulqader Abufares, al-Nezam ul-Siyasi fil Islam, Jordan: Dar ol-Furqan, 1986, pp. 131-150; Mohammad al-Bahi, al-Din val Dowlah min Towjihi Quran al-Karim, Beirut: Dar ol-Fikr, 1391 AH/1971, pp. 371-543; Abdulkarim al-Khatib, al-Khilafah val Imamah, Beirut: Dar ol-Ma'refah, 1359 AH/1975, pp. 169-192; Samir Aliyah, Nazariyah al-Dowlah va Adaabuha fil Islam, Beirut: al-Muassisah al-Jame'iyah Leldirasat val Nashr val Tozi, 1408 AH/1998, pp. 31-41; Ahmad Hossein Yaghoub, al-Nizam al-Siyasi fil Islam, Beirut: al-Dar al-Islamiyah, 1417 AH/1996, pp. 257-270; Abdulhei bin Abdulkabir al-Katani, Nezam al-Hokumah al-Nabawiyah, comments: Ali Mohammad Dandal, Beirut: Dar ul-Kotob al-Ilmiyah, 1422 AH/2001, pp. 275-300; Khalil Abdulkarim, Dowlatah Yathrib, Egypt: Sina Lilnashr va Moassissah al-Intishar al-Arabi, 1999.

[iii] See: Sohrevardi, Hikmat-ul-Ishraq, vol. 3, p. 380 and pp. 18-20

[iv] Ali Akbar Alikhani, Political Thought of Muslim Thinkers (19 volumes) Tehran: Research Institute for Social and Cultural Studies' press, 2011, Vol.1, pp. $2-4$.

[v] To review this issue from another angle, see: Hassan Hanafi, "al-Fithqah wal Torath", in "al-Falsafatil Arabiyah al-Muasir", Beirut: Dirasat al-Wahdah al-Arabiyah Center, 1988, p. 379; Hassan Hanafi, Homum al-Fikr wal Watan”, al-Qahirah dar ol-Qoba, 1998, pp. 14-15

[vi] see: Ail Akbar Alikhani, Islamic Political

Hikmat(Philosophy)Foundational Concepts, Tehran: Iranian Institute of

Philosophy Press, 2015, pp. 2-65.

[vii] With regard to nature of figh, See: Mostafa Malekian et al., "Discourses of Philosophy of Fiqh", Qom: Office for Promoting of Islamic Culture Press, 1998, Abdolmajid Moballeghi, Innovation and Religious Studies, Qom: Research Institute for Islamic culture and Knowledge, 20013.

[viii] See: Abolfazl Shakouri, Political Fiqh of Islam, Qom: Office for Islamic Propagation Press, 1998; Abbasali Amid Zanjani, Political Fiqh: International Rights and Commitments and Diplomacy in Islam, Tehran, Samt Press

[ix] See: Yousef al-Qarzawi, Min Fiqh al-Dowlah fil Islam, Cairo, Dar ol-Shorouq, 1419 AH/1999; Farid Abdulhaq, Fil Fiqh al-Siyasi al-Islami, Cairo, Dar ol-Shorouq, 1419 AH/1999

[x] See: Ali Akbar Rashad, op. cit., pp. 53-78; Hassan Abbas Hassan, Logical Structure of Political Thought of Islam, Mostafa Fazaeli, Qom: Boustan Ketab Press, 2004, pp. 236-342

[xi] See: Sharif Lakzaei, "A Study of Situation of Political Philosophy in Iran", Pazhouhesh va Hozeh (Research and Seminary) quarterly, No. 21-22, p. $115,2006$.

[xii] See: Nasr Mohammad Aref, op. cit.; pp. 40, 46-48

[xiii] See: Hassan Hanafi, "The Middle East, in Whose World?", the Fourth Nordic Conference on Middle East Studies: The Middle East in Globalizing World, Oslo, August 13-16, 1998

[xiv] See: Nasr Mohammad Aref, op. cit., p. 54

[xv ] See: Abdulrahman al-Badwi, Usul al-Yunaniyah Lel-Nazariyat al-Islamiyah al-Siyasiyah, Cairo, Maktabatol Nehzatol Mesriyah, 1954, p. 72

[xvi] Nasr Mohammad Aref, op. cit., p. 53; Hassan Hanafi and Mohammad Abed al-Jaberi, "Dialogue of Two Cultures", translated by Mohammad Mehdi Khalaji, Critique and Viewpoint, No. 9, winter 1996, pp. 243-4 [xvii] Nasr Mohammad Aref, op. cit., p. 53; Hassan Hanafi and Mohammad Abed al-Jaberi, "Dialogue of Two Cultures", translated by Mohammad Mehdi Khalaji, Critique and Viewpoint, No. 9, winter 1996, pp. 243-4 [xviii] See: Yousef al-Qarzawi, op. cit.

[xix] Fouad Zakaria, philosophy prospectes, Beirut: Dar al Tanvir, press, 1988 , P.P.413 \& 380-383. 